\title{
Inventory of the specimens of the Class Crinoidea (Echinodermata) deposited at the Invertebrates collection at the Museo Argentino de Ciencias Naturales "Bernardino Rivadavia"
}

\author{
Renata M. PERTOSSI ${ }^{1 *} \&$ Mariano I. MARTINEZ \\ ${ }^{1}$ Laboratorio de Ecosistemas Costeros, Plataforma, Aguas Profundas y Malacología, Museo Argentino de \\ Ciencias Naturales "Bernardino Rivadavia" (MACN-CONICET), Av. Ángel Gallardo 470 (C1405DJR), Buenos \\ Aires, Argentina. "Email: pertossi.renata@gmail.com
}

\begin{abstract}
The invertebrate collection of the Museo Argentino de Ciencias Naturales "Bernardino Rivadavia" (MACN-In) is one of the most important in Latin America. It has more than 1411 type batches with 90 type specimens of echinoderms. For the present study we analyzed 56 lots of crinoids from the MACN-In. We also checked and updated the identification, when necessary. Seven species belonging to 6 genera were identified; 23 specimens remain unidentified. The diversity of crinoids for Chile, Uruguay and Brazil and Antarctica is discussed. The MACN-In has several lots of crinoids from different parts of the world and numerous specimens of the 2 representative species from Argentina, Isometra vivipara Mortensen, 1917 and Phrixometra nutrix (Mortensen, 1918). This is the first published inventory of crinoids from samples deposited at the MACN-In collection, which will be a useful tool for future studies regarding echinoderms, particularly crinoids.
\end{abstract}

Key words: crinoids, Argentina, Antarctica, MACN-In, lots.

Resumen: Inventario de los ejemplares de Clase Crinoidea (Echinodermata) en la colección de Invertebrados del Museo Argentino de Ciencias Naturales "Bernardino Rivadavia”. La colección de invertebrados del Museo Argentino de Ciencias Naturales "Bernardino Rivadavia" (MACN-In) es una de las más importantes de América Latina. Tiene más de 1411 lotes tipo con $\sim 90$ ejemplares tipo de equinodermos. Para el presente estudio analizamos 56 lotes de crinoideos del MACN-In. También verificamos y actualizamos la identificación, cuando fue necesario. Siete especies pertenecientes a 6 géneros; 23 especímenes permanecen sin identificar. Se discutió la diversidad de crinoideos para Chile, Uruguay, Brasil y Antártida. El MACN-In cuenta con varios lotes de crinoideos de diferentes partes del mundo y numerosos ejemplares de las 2 especies representativas de Argentina, Isometra vivipara Mortensen, 1917 y Phrixometra nutrix (Mortensen, 1918). Este es el primer inventario publicado de crinoideos a partir de muestras depositadas en la colección MACN-In, el cual será una herramienta útil para futuros estudios sobre equinodermos, particularmente crinoideos.

Palabras clave: crinoideos, Argentina, Antártida, MACN-In, lotes

\section{INTRODUCTION}

The Museo Argentino de Ciencias Naturales "Bernardino Rivadavia" (MACN) is one of the most important museums of Latin America, with 23 national collections, including the MACN-In ("Colección Nacional de Invertebrados"). This collection has more than 1411 type lots, with more than $\sim 90$ type specimens of echinoderms (Tablado \& Venerus, 2000; Tablado \& Mantinián, 2004; Miquel et al., 2007). Biodiversity research of echinoderms from South America increased in the last years (Alvarado \& Solís-Marín, 2013). Particularly, for the Argentine Sea, several re- searchers have been studying their reproductive, ecological, biogeographical, taxonomical, and physiological aspects (Brogger et al., 2013; Martinez et al., 2015; Pertossi et al., 2019). Echinoderms in Argentina are represented by 126 species, where Asteroidea and Ophiuroidea are the most representative groups (Brogger et al., 2013).

The Class Crinoidea is one of the five current classes in the phylum Echinodermata with $\sim 670$ living species, distributed in all oceans (WoRMS Editorial Board, accessed 26 July 2021). The most diverse group within this class is Comatulida, commonly called "feather 
stars" or "unstalked crinoids". It is represented by approximately 140 genera and $\sim 500$ species. Nevertheless, unstalked crinoids are not ontogenetically accurate because the adult of comatulids retains the proximal portion of the juvenile stalk (Hyman, 1955; Hendler et al., 1995; Messing, 1997), i.e., a large modified centrodorsal ossicle that represents a reduced stalk (Hendler et al., 1995; Cohen et al., 2004; Pawson, 2007). In Argentina, the research on crinoids is very scarce. Andersson (1904), Mortensen (1917, 1918, 1920), John (1938), Clark and Clark (1967) and, Speel and Dearborn (1983) began studying the reproduction and taxonomy of Isometra vivipara Mortensen, 1917 and Phrixometra nutrix (Mortensen, 1918), whereas Tommasi described I. vivipara with specimens from Brazil (Tommasi 1969, Tommasi et al., 1988d). But, in Argentina, Bernasconi was the first researcher to study echinoderms (Bernasconi 1932, 1934), including the Antarctic species Promachocrinus kerguelensis. Pertossi et al. (2019) studied the reproduction and developmental stages of the crinoid $I$. vivipara. There are only two species of comatulid crinoids recorded in Argentina: Isometra vivipara and Phrixometra nutrix, included in the Family Antedonidea (Brogger et al., 2013). The knowledge on taxonomy, biology, and ecology of crinoids in South America is limited (Tommasi, 1969; Bohn, 2009; Martínez et al., 2018; Martinez, 2013; Ventura et al., 2013; Catalán et al., 2020), probably due to the lack of researchers working on this group. Furthermore, considering that crinoids are deep-sea animals, the access to the samples is not always easy and has higher costs than studying coastal or shallow water species (Eleáume et al., 2014, Ventura et al., 2013).

The present contribution aims to provide a complete inventory of the specimens of the Class Crinoidea deposited at the National Invertebrates collection of the Museo Argentino de Ciencias Naturales "Bernardino Rivadavia" (MACN-In). The specimens of echinoderms present in Argentina according to Brogger et al. (2013) were compared with the latestdatabase of MACN-In. Moreover, we examined and updated their identifications and records.

\section{MATERIAL AND METHODS}

We studied 56 lots of crinoids from the MACN-In. Observations were carried out under a stereoscopic microscope; images were taken with a Stereo Discovery.V20 and an Axiocam HRc digital camera. All diagnostic characters were analyzed in detail i.e., the cirri, basal, radial and axillary ossicles (IBr1-IBr2) oral pinnules (P1-P2-P3), genital pinnules (Pg), and arm number. We analyzed all the information of each specimen from the collection database (Pennant, 1777; Lamarck, 1816; Pourtalès, 1868; Carpenter, 1888; Bernasconi 1932, 1934; John, 1938; Clark \& Clark, 1967; Mortensen, 1917; Mortensen, 1918; WoRMS Editorial Board, accessed 26 July 2021)). The location of each specimen was represented on a map (Fig. 1). Complementarily, we provided images of the two crinoid species recorded in Argentina, Isometra vivipara and Phrixometra nutrix (Fig. 2) and very well represented in this collection. All this data from the MACN-In specimens was compared with those described in near water areas, including Chile, Brazil, Uruguay and Antarctica. Finally, we compared the specimens of echinoderms present in Argentina according to Brogger et al. (2013) with the latest database of the MACN-In.

\section{RESULTS}

The 56 studied lots of crinoids deposited at the MACN-In were composed of 286 specimens from 7 species belonging to 6 genera and 4 families: Antedonidae, Charitometridae, Comatulidae, and Tropiometridae, all of them belonging to the order Comatulida. For all the identified specimens we observed and provided below the diagnostic characters to corroborate their identification. The specimens studied here came from different locations, including Argentina, Antarctica, Brazil, Cuba, Japan, and the Mediterranean Sea (Fig. 1). Although several specimens were identified, 23 remained unidentified, mainly due to their poor state of preservation. They were damaged and parts were missing (i.e., cirri, arms, and centrodorsal ossicles), which made it impossible to observe diagnostic characters. The two species described for Argentina, Isometra vivipara, and Phrixometra nutrix (Fig. 2), are well represented in the collection with 256 specimens (Table 1). In addition, 74 of the 126 species of echinoderm present in Argentina are registered in the MACN-In collection, being the classes Crinoidea and Echinoidea the most represented (Table 2).

Crinoids from the MACN-In

Antedon bifida bifida (Pennant, 1777)

Studied material. MACN-In 4300, 1 specimen, 1898, label: "Mar Mediterráneo" (Mediterranean Sea). It was acquired by the MACN through a 


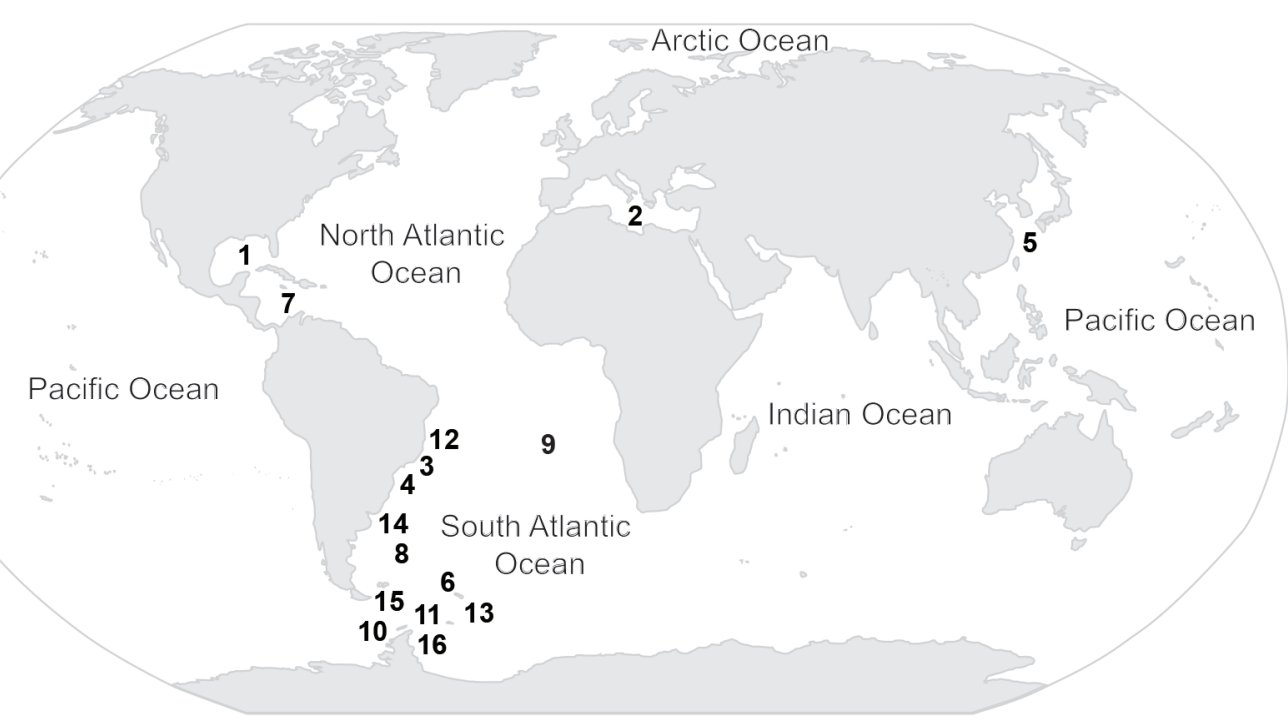

Fig. 1. Map showing the distribution of the specimens. The numeration indicates the locality of MACN-In from Table 1.

purchase from Est. Zool. Naples.

Diagnosis (amended from Clark \& Clark, 1967): P2 is the same length as P3 and resembles it, though it does not bear a gonad; P1 is composed of more than 25 segments; there are no more than 18 cirrus segments of which the outer ones are moderately compressed laterally, the cirri rarely exceed 40 in number; the IBr1 are very short, especially in larger specimens, and the slightly converging lateral edges form distinct angles with the projecting lateral corners of the axillaries.

Remarks. We updated the name of the lot MACN-In 4300 that included specimens of the species Antedon rosacea (Pennat, 1777), subsequently identified as Antedon bifida bifida (Pennant, 1777). These specimens have a distribution from the Shetland and South Orkney Islands to northern Spain and most of Portugal (Clark \& Clark, 1967), which also agrees with the distribution of the lot.

Tropiometra carinata (Lamarck, 1816)

Studied material. MACN-In 7868, 1 specimen, label: "San Pablo, Brasil" (San Pablo, Brazil).

Diagnosis (amended from Lamarck, 1816): 10 pinnate rays and 20 claws or dorsal cirri.

Remarks. In the case of Tropiometra carinata little is known of its patterns of distribution. Although Lamarck (1816) reported this species in France, other authors such as Tommasi (1965) and MarcCood \& Duarte (2002) found T. carinata on the Brazilian coast. Besides, it was registered at Andaman and Nicobar Islands in the Indian
Sea (Nigam \& Raghunathan, 2015). According to the diagnosis of this species, the characters agree with the accessioned sample (MACN-In 7868).

Promachocrinus kerguelensis (Carpenter, 1888)

Studied material. MACN-In 18707, 1 specimen, $23 \mathrm{~m}$; MACN-18708, 6 specimens, $27 \mathrm{~m}$, 1929, label: "Islas Georgias del Sur", (South Georgia Islands); MACN-In 26984, 1 specimen, 1965, label: "Archipiélago Melchior" (Melchior Archipelago); MACN-In 27711, 6 specimens, 80 m, 1973 label: "Islas Georgias del Sur", (South Georgia Islands).

Diagnosis (amended from Carpenter, 1888): P1 and P2 are similar, $20 \mathrm{~mm}$ in length. The first brachial ossicle is scarcely incised by the second. First radial ossicles barely visible; second ossicles short, nearly oblong, and but slightly joined laterally. Centrodorsal plate conical and thickly covered almost to the apex with 80 or more cirri that may reach $40 \mathrm{~mm}$ in length, and consist of 35 to 40 joints, which are mostly longer than wide. The later joints may slightly overlap, but the penultimate is small, with little or no trace of an opposing incised spine.

Remarks. Lots MACN-In 18707 and MACNIn 18708 were identified and studied by Irene Bernasconi (Bernasconi 1932, 1934). As far as we know, it is the only reference of a paper and she was the only one who identified these crinoid specimens at MACN.

Crinometra brevipinna (Pourtalès, 1868)

Studied material. MACN-In 20514, 1 specimen, 1932, label: "Mar Caribe" (Caribbean Sea). 
Diagnosis (amended from Pourtalès, 1868: 111): P1 longest, with about 12 joints. The other pinnules are very short, having only 5 or 6 joints in the middle of the arm, the last ones being tipped with a hook-like cirri. Ten arms with joints slightly imbricate. Approximately 15 cirri, with the same number of long articulations. The two radials are visible and have a smooth tubercle in the middle, as well as the axial and the two first brachials.

Remarks. Crinometra brevipinna (Pourtalès, 1868) is distributed from northern and eastern Gulf of México; coasts of Cuba to Barbados and Grenada, including Jamaica; Caribbean coast of central and South America and southward to the coast of Rio Grande do Sul, Brazil (Meyer et al., 1978). This agrees with the distribution of the lot MACN-In 20514 previously identified as $C$. brevipinna, which was correctly labeled and checked here.

\section{Isometra vivipara Mortensen, 1917}

Studied material. MACN-In 22821: $54^{\circ} 50^{\prime} \mathrm{S}-$ $64^{\circ} 01^{\prime} \mathrm{W}, 1$ specimen, $151 \mathrm{~m}, 1935$. MACN-In 22822: $54^{\circ} 57^{\prime} \mathrm{S}-64^{\circ} 42^{\prime} \mathrm{W}, 12$ specimens, $265 \mathrm{~m}$, 1935, labels: "Atlántico Sur" (South Atlantic).

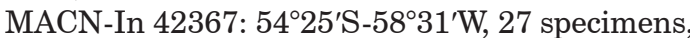
$137 \mathrm{~m}$. MACN-In 42368: 54 $51^{\circ}$ 'S- $60^{\circ} 0^{\prime} \mathrm{W}, 25$ specimens, $159 \mathrm{~m}$. MACN-In 42369: $54^{\circ} 32^{\prime} \mathrm{S}-60^{\circ} 1.2^{\prime} \mathrm{W}$, 3 specimens, $98 \mathrm{~m}$ depth. MACN-In 42370: $54^{\circ} 10^{\prime} \mathrm{S}-58^{\circ} 16^{\prime} \mathrm{W}, 2$ specimens, $100 \mathrm{~m}$. MACNIn 42371: $54^{\circ} 11^{\prime} \mathrm{S}-58^{\circ} 19^{\prime} \mathrm{W}, 1$ specimen, $95 \mathrm{~m}$. MACN-In 42372 : $54^{\circ} 30^{\prime} \mathrm{S}-59^{\circ} 52^{\prime} \mathrm{W}, 8$ specimens, 109 m. MACN-In 42373: $54^{\circ} 37^{\prime} \mathrm{S}-61^{\circ} 9^{\prime} \mathrm{W}, 4$ specimens, 202 m. MACN-In 42374: $54^{\circ} 28^{\prime} \mathrm{S}-59^{\circ} 13^{\prime} \mathrm{W}$, 4 specimens, 128 m. MACN-In 42375: $54^{\circ} 32^{\prime} \mathrm{S}-61^{\circ} 26^{\prime} \mathrm{W}, 20$ specimens, $125 \mathrm{~m}$. MACNIn 42376: $54^{\circ} 35^{\prime} \mathrm{S}-58^{\circ} 38^{\prime} \mathrm{W}, 1$ specimen, $140 \mathrm{~m}$. MACN-In 42377: $54^{\circ} 36^{\prime} \mathrm{S}-62^{\circ} 51^{\prime} \mathrm{W}, 3$ specimens, 608 m. MACN-In 42378: 54 $24^{\circ}$ 'S- $58^{\circ} 28^{\prime} \mathrm{W}, 8$ specimens, $95 \mathrm{~m}, 2016$, labels: "Area Marina Protegida Namuncurá/Banco Burdwood" (Burdwood Bank/MPA Namuncurá). MACNIn 42379: $55^{\circ} 6^{\prime} \mathrm{S}-65^{\circ} 44^{\prime} \mathrm{W}, 9$ specimens, $263 \mathrm{~m}$. MACN-In 42380 : $54^{\circ} 52^{\prime} \mathrm{S}-64^{\circ} 16^{\prime} \mathrm{W}, 36$ speci-

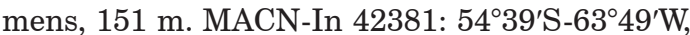
2 specimens, $143 \mathrm{~m}$. MACN-In 42382: $54^{\circ} 24^{\prime} \mathrm{S}-62^{\circ} 49^{\prime} \mathrm{W}, 4$ specimens, $483 \mathrm{~m}$. MACN-In 42383: $54^{\circ} 26^{\prime} \mathrm{S}-58^{\circ} 32^{\prime} \mathrm{W}, 13$ specimens, $138 \mathrm{~m}$. MACN-In 42384: $54^{\circ} 26^{\prime} \mathrm{S}-59^{\circ} 30^{\prime} \mathrm{W}, 6$ specimens, $91 \mathrm{~m}$. MACN-In 42385: $53^{\circ} 40^{\prime} \mathrm{S}-61^{\circ} 38^{\prime} \mathrm{W}, 3$ specimens, $642 \mathrm{~m}$. MACN-In 42386: $53^{\circ} 34^{\prime} \mathrm{S}-63^{\circ} 58^{\prime} \mathrm{W}$, 2 specimens, 263 m. MACN-In 42387: $53^{\circ} 34^{\prime} \mathrm{S}-62^{\circ} 58^{\prime} \mathrm{W}, 2$ specimens, $516 \mathrm{~m}$. MACNIn 42388: $53^{\circ} 49^{\prime} \mathrm{S}-61^{\circ} 28^{\prime} \mathrm{W}, 4$ specimens, $209 \mathrm{~m}$.
MACN-In 42389: $53^{\circ} 49^{\prime} \mathrm{S}-61^{\circ} 19^{\prime} \mathrm{W}, 8$ specimens,

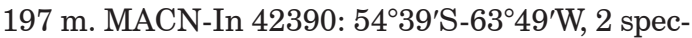
imens, 143 m, 2017, labels: Burdwood Bank/MPA Namuncurá.

Diagnosis (amended from Clark \& Clark, 1967): $\mathrm{P} 1$ is up to $10.5 \mathrm{~mm}$ long with 10 to 17 segments, whereas P2 is usually 1.5 to $2.0 \mathrm{~mm}$ shorter with 9 to 14 segments and no longer than $8.5 \mathrm{~mm}$.; P5 is usually the first genital pinnule, with 26-43 cirri, the longest segments hardly, if ever, longer than wide.

Remarks. The specimens MACN-In 28821 and MACN-In 28822 were studied by Bernasconi who largely contributed to subsequent studies. Also, Pertossi et al. (2019) studied the reproduction and developmental stages in the crinoid $I$. vivipara.

\section{Phrixometra nutrix (Mortensen, 1918)}

Studied material. MACN-In 39870: $38^{\circ} 51^{\prime}$ S$55^{\circ} 35^{\prime} \mathrm{W}, 5$ specimens, $145 \mathrm{~m}, 2009$, MACN-In 43242: $38^{\circ} 51^{\prime} \mathrm{S}^{\prime \prime} \mathrm{S}-55^{\circ} 34.58^{\prime} \mathrm{W}, 1$ specimen, 140 m, 2009, MACN-In 43243: $38^{\circ} 51^{\prime} \mathrm{S}-55^{\circ} 34^{\prime} \mathrm{W} 7$ specimens, $140 \mathrm{~m}, 2009$, labels: "Talud continental" (Continental slope). MACN-In 43244: $61^{\circ} 49.6^{\prime} \mathrm{S}-57^{\circ} 34.4^{\prime} \mathrm{W}, 1$ specimen, $210 \mathrm{~m}, 2011$, label: "Antártida" (Antarctica). MACN-In 43245: $37^{\circ} 57.9^{\prime} \mathrm{S}-55^{\circ} 12.73^{\prime} \mathrm{W}, 1$ specimen, $201 \mathrm{~m}$, 2012, label: "Talud continental" (Continental slope). MACN-In 43246: $54^{\circ} 27^{\prime} \mathrm{S}-60^{\circ} 58^{\prime} \mathrm{W}$, 1 specimen, $100 \mathrm{~m}, 2016$, label: Burdwood Bank/MPA Namuncurá. MACN-In 43247: $53^{\circ} 49^{\prime} \mathrm{S}-61^{\circ} 28^{\prime} \mathrm{W}, 1$ specimen, 209 m. MACN-In 43248: $54^{\circ} 36^{\prime} \mathrm{S}-61^{\circ} 30^{\prime} \mathrm{W}, 2$ specimens, $294 \mathrm{~m}$. MACN-In 43249: $54^{\circ} 51^{\prime} \mathrm{S}-63^{\circ} 52^{\prime} \mathrm{W}, 2$ specimens, 330 m. MACN-In 43250: $55^{\circ} 5.5^{\prime} \mathrm{S}-60^{\circ} 41.9^{\prime} \mathrm{W}$, 5 specimens, 122 m. MACN-In 43251: $54^{\circ} 48.79^{\prime} \mathrm{S}-63^{\circ} 45.91^{\prime} \mathrm{W}, 1$ specimen, $278 \mathrm{~m}$. MACN-In 43252 : $59^{\circ} 26^{\prime} \mathrm{S}-59^{\circ} 30^{\prime} \mathrm{W}, 7$ specimens, $91 \mathrm{~m}$. MACN-In 43253: $54^{\circ} 5.2^{\prime} \mathrm{S}-60^{\circ} 53^{\prime} \mathrm{W}, 3$ specimens, 132 m. MACN-In 43254: $53^{\circ} 31^{\prime} \mathrm{S}-63^{\circ} 1.8^{\prime} \mathrm{W}$, 1 specimen, 512 m, 2017, labels: Burdwood Bank/ MPA Namuncurá.

Diagnosis (amended from Clark \& Clark, 1967): P1 has approximately 14 segments; P2 is usually the first genital pinnule and similar in length and number of segments to P1; the cirri of these crinoids are approximately 45 , with less than 20 segments.

Remarks. $P$. nutrix is distributed in South America, from the Magallanes Region, in the Pacific Ocean, to the Namuncurá / Burdwood Bank Marine Protected Area, in the Atlantic Ocean, and Antarctica, from the Antarctic Peninsula and some Subantarctic Islands (Spell 


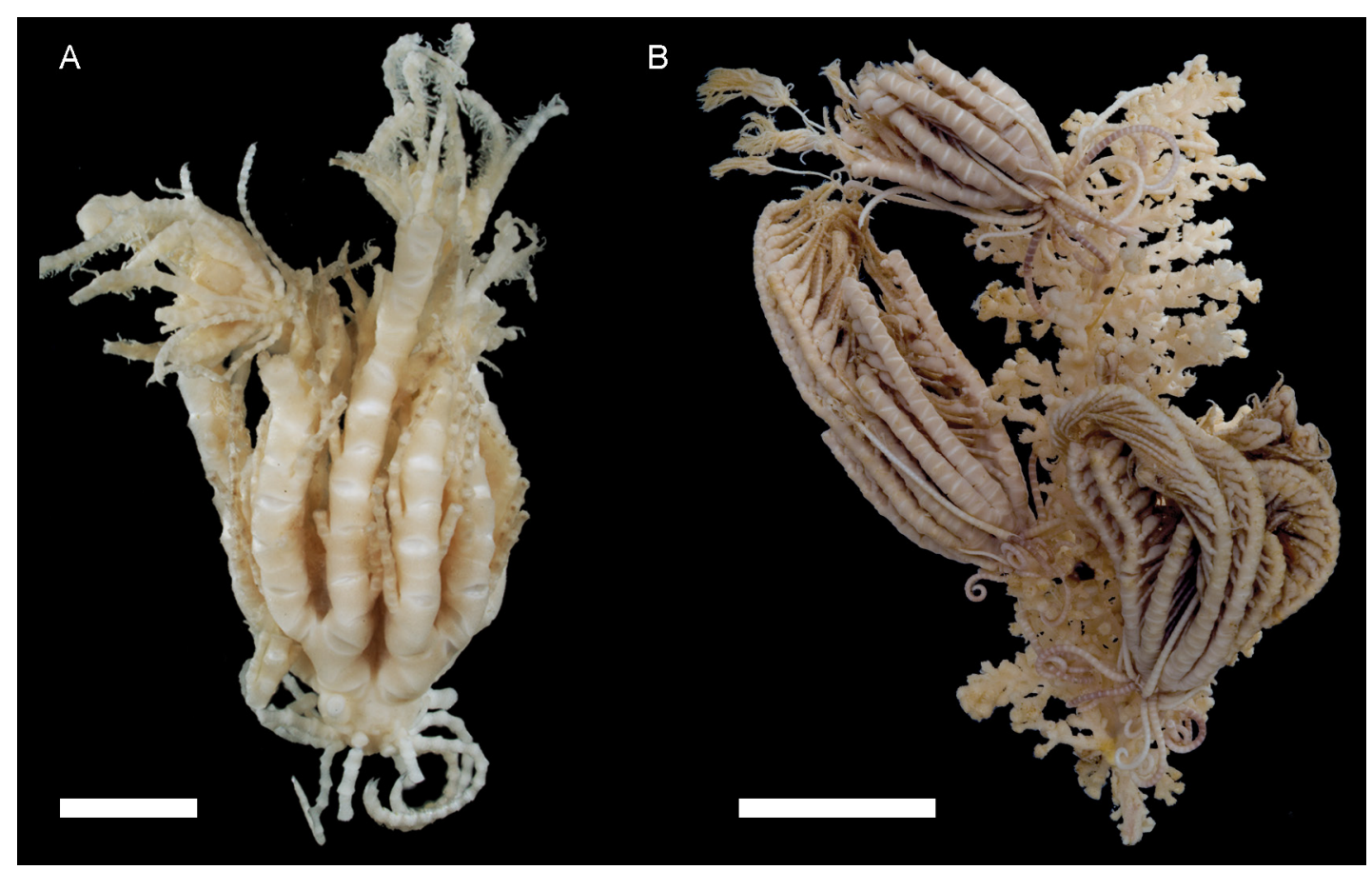

Fig. 2. Crinoids of Argentina. A, Phrixometra nutrix. B, Isometra vivipara. Scale bars: A 2 mm; B 2 cm.

\& Dearborn, 1983). We incresed their distribution near the Mar del Plata Submarine Canyon area ( $\left.38^{\circ} 51^{\prime} \mathrm{S}-55^{\circ} 35^{\prime} \mathrm{W}, \mathrm{MACN}-38970\right)$. Additionally, we updated the bathymetric range from 150 to 200m (Clark \& Clark, 1967) to 512 m (Pertossi et al., 2021).

Isometra hordea John, 1938

Studied material. MACN-42993: $63^{\circ} 23^{\prime} \mathrm{S}-$ $57^{\circ} 00^{\prime} \mathrm{W}, 1$ specimen, $260 \mathrm{~m}$ depth. Collected in "Bahía Esperanza, Antártida" (Hope Bay, Antarctica).

Diagnosis (amended from Clark \& Clark, 1967): the cirri are 40-62 with 25-75 segments; the first two pinnules are relatively small, especially P1, which does not exceed $5 \mathrm{~mm}$ in length; the first genital pinnule is usually P5; in the female, the third to seventh segments of the genital pinnules are usually expanded; this is a very large species with a length reaching up to $17 \mathrm{~mm}$ from the proximal edge of the IBr1 to the second syzygy at $9+10$.

Remarks. We identified the specimen MACNIn 42993 as Isometra hordea John, 1938. The distribution of I. hordea is South Africa, South Shetlands, South Orkneys, and off Cape Adare in the Ross Sea. Here we report it in Hope Bay at $260 \mathrm{~m}$. All the characteristics observed resemble this species, like pinnule in position 2 (P2) being longer than $\mathrm{P} 1$, the number of the cirri between 25-75, and up to 70 segments, the first genital pinnule is usually P5 (John, 1938; Clark \& Clark, 1967; Spell \& Dearbon, 1983) (Table 1)

\section{DISCUSSION AND CONCLUSION}

Echinoderms are well represented along the Argentine coast with more than 126 living species described, represented by 58 species of asteroids, 30 ophiuroids, 25 holothuroids, 12 echinoids, and 2 crinoids (Brogger et al., 2013; O’Loughlin et al., 2011; Martinez et al., 2015). According to this, representatives of the only two known species of Crinoidea recorded in Argentina are deposited at MACN-In. By contrast, only $60 \%$ of the Asteroidea species recorded from Argentina are represented in the MACN-In, as well as, $65 \%$ of Ophiuroidea, $100 \%$ of Echinoidea, and $32 \%$ of Holothuroidea. Of the 56 lots of the studied crinoids, $70 \%$ of the specimens are from the Southwestern Atlantic Ocean and the Antarctica, while the others proceed from the Caribbean area, Mediterranean Sea, and Japan.

In Chile, Uruguay, and Brazil, the research of crinoids is limited. In Chile, the crinoid diversity is composed of five species of comatulids: 


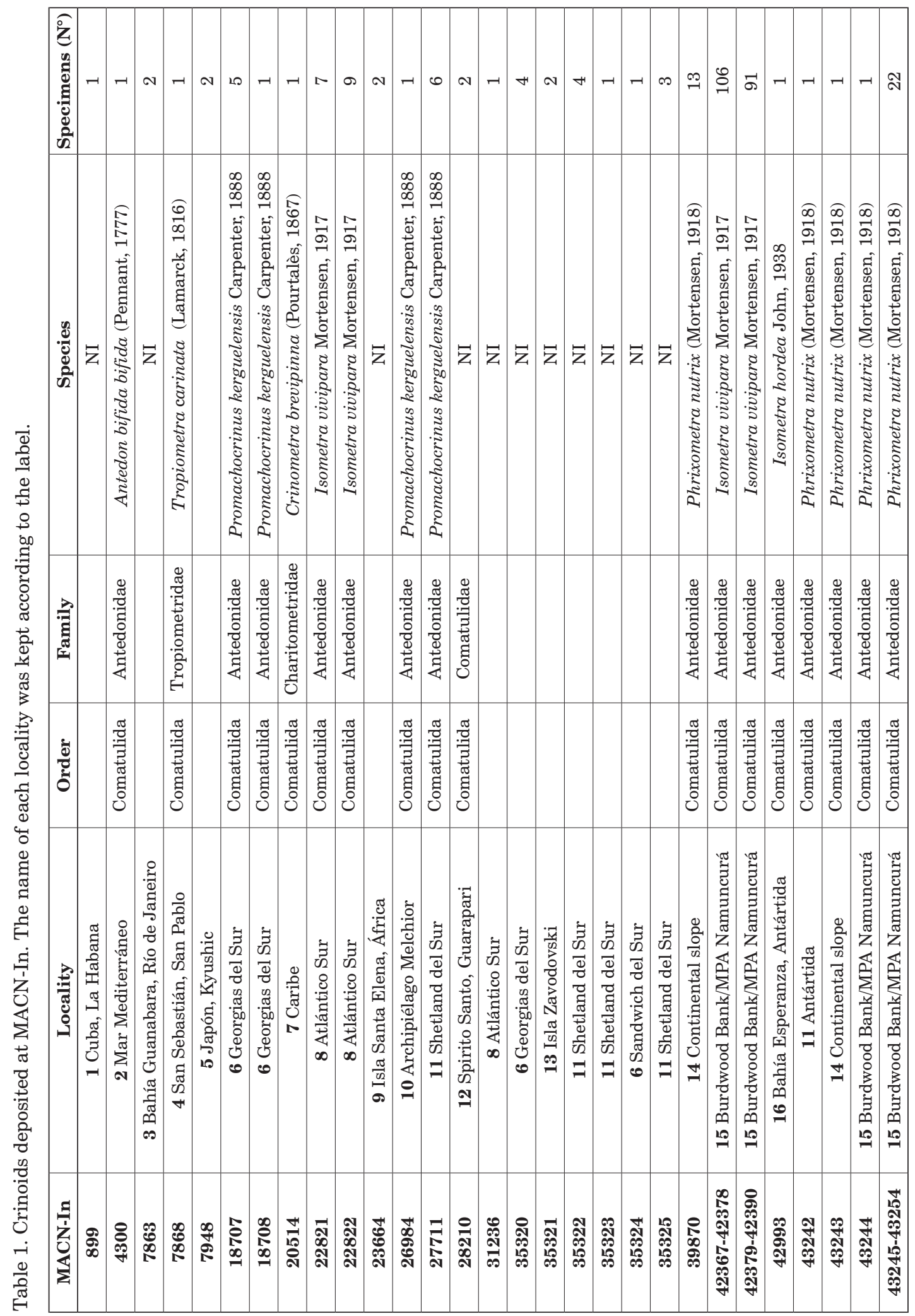


Table 2. Echinoderms registered in Argentina vs. echinoderms of Argentina deposited at MACN-In.

\begin{tabular}{ccc}
\hline Class & $\begin{array}{c}\text { Echinoderm spe- } \\
\text { cies recorded in } \\
\text { Argentina }\end{array}$ & MACN-In \\
\hline Crinoidea & 2 & $2(100 \%)$ \\
Asteroidea & 57 & $34(60 \%)$ \\
Ophiuroidea & 30 & $18(60 \%)$ \\
Echinoidea & 12 & $12(100 \%)$ \\
Holothuroidea & 25 & $8(32 \%)$ \\
\hline
\end{tabular}

Florometra magellanica (Bell, 1882), Isometra vivipara, Phrixometra nutrix, Promachocrinus kerguelensis, and Solanometra antarctica (Carpenter, 1888) (Bohn, 2009; Catalán et al., 2020). The eastern South Pacific Ocean shares two crinoids with the southwestern Atlantic Ocean, $I$. vivipara and $P$. nutrix. In the present contribution, no species of Crinoidea were registered of the 37 species of echinoiderms reported from Uruguay (Martinez, 2013). According to Martinez (2013), there has been no systematic sampling of the Uruguayan waters, therefore the proportion among classes might not be reliable. Moreover, considering that research-oriented faunistic surveys have been scarce, except for recent years, and that the diversity of species in the collections has not been studied, it can be said that the number of species is not very clear (Martinez, 2013). In Brazilian waters, 16 crinoids species have been reported (Ventura et al., 2013). Among them, specimens of Tropiometra carinata could be found deposited at the MACNIn collection under the number \#7868 (Table 1). MacCord \& Duarte (2002), described the dispersion pattern and size structure of the crinoid $T$. carinata along the southeastern Brazilian coast (MacCord \& Duarte, 2002; Ventura et al., 2013). Of the 44 crinoid species recorded in Antarctica (Eléaume et al., 2014), the MACN-In collection houses specimens of only 4 species: Isometra hordea, Isometra vivipara, Phrixometra nutrix, and Promachocrinus kerguelensis.

In Argentina, research on the Phylum Echinodermata has been increasing in the last years (Brogger et al., 2013; Martinez et al., 2015), but crinoids are still one of the most enigmatic groups in the region. This inventory provides updated information on the Crinoidea collection deposited at the Museo Argentino de Ciencias Naturales "Bernardino Rivadavia", Buenos Aires, Argentina, and constitutes a valuable tool for fu- ture studies dealing with echinoderms and, particularly, those pertaining to the Class Crinoidea

\section{ACKNOWLEDGMENTS}

The authors would like to express their gratitude to Alejandro Tablado and Dr. Mariela Romanelli for providing us with the necessary information for this work. Also, we thank Andrea Martinez for her help and constribution. We also thank the reviewers for theirs comments that enriched this paper. This study was funded by PICT 2016-0271, PICT 2016-0211, PICT 2016-01127 and by PIP 11220170100643CO. Scientific surveys at the Burdwood Bank were funded through the National Law 26.875 of creation of the MPA Namuncurá. This is the contribution number 51 to the Area Marina Protegida Namuncurá.

\section{REFERENCES}

Alvarado J.J. \& F.A. Solís-Marín. 2013. Echinoderm Research and Diversity in Latin America. In: Alvarado J., Solis-Marin F. (eds) Echinoderm Research and Diversity in Latin America, pp. 1-658, Springer, Berlin, Heidelberg.

Andersson, K.A. 1904. Brutpflege bei Antedon hirsuta Carpenter. In: Lithographisches Institut de Generalstabs (eds). Wiss Ergeb Schwedische Südpolar-Exped 5: 1-7.

Bell, F.J. 1882. Note on a crinoid from the Straits of Magellan. Proceeding of the Zoological Society of London 6: 650-652.

Bernasconi, I. 1932. Notas sobre un crinoideo de Sud Georgia. Revista del Museo Argentino de Ciencias Naturales 37: 29-35.

Bernasconi, I. 1934. Los equinodermos de los mares argentinos. Revista del Museo Argentino de Ciencias Naturales 53: 1-21.

Bohn, J. 2009. Crinoidea - Sea lilies and feather stars. In: Häussermann V, Försterra G (eds.) Marine Benthic Fauna of Chilean Patagonia, pp. 793-800, Santiago, Nature in Focus.

Brogger, M.I., D.G. Gil, T. Rubilar, M.I. Martinez, M.E. Díaz de Vivar, M. Escolar, L. Epherra, A.F. Pérez \& A. Tablado 2013a. Echinoderms from Argentina: biodiversity, distribution and current state of knowledge, In Alvarado J.J. and Solís-Marín F.A. (eds.) Echinoderms research and diversity in Latin America, pp. 359-402, Berlin, Germany: Springer.

Carpenter, P.H. 1888. Report on the Crinoidea Zoology 32 XXXII. Second Part.-Comatulæ. In: Report on the Challenger Expedition, 26, pp. 399, London.

Catalán J., C. Merino-Yunnissi, A. Martínez, J. Sellanes \& C.M. Ibáñez. 2020. Nuevos registros de crinoideos (Echinodermata: Crinoidea) en el talud continental de Chile. Revista de Biología Marina y Oceanografía 55: 68-72.

Clark, A.H. \& A.M. Clark,. 1967. A monograph of the existing crinoids, Vol. 1: the comatulids, part 5, Suborders Oligophreata (concluded) and Macrophreata, 82, pp. 1-860, Bulletin - United States 
National Museum.

Cohen, B.L., N. Ameziane, M. Eleaume \& B.R. De Forges. 2004. Crinoid phylogeny: a preliminary analysis (Echinodermata: Crinoidea). Marine Biology 144: 605-617.

Eléaume M., L.G. Hemery, M. Roux \& N. Améziane 2014. Echinodermata: Crinoidea. In: De Broyer C., Koubbi P., Griffiths H. J., et al. (eds.), The Biogeographic Atlas of the Southern Ocean, pp. 208-212, Scientific Committee on Antarctic Research, Cambridge.

Hendler, G., J.E. Miller, D.L. Pawson \& P.M. Kier. 1995. Sea stars, sea urchins and allies, Echinoderms of Florida and the Caribbean. Smithsonian Institution Press $390 \mathrm{pp}$.

Hyman, L.H. 1955. Class Crinoidea. In: E.J. Boell et al. Echinodermata. The Coelomate Bilateria, 5, pp. 34-118, McGraw-Hill Book Company.

John, D.D. 1938. Crinoidea. Discovery Reports 18: 123-211.

Lamarck, J.B.M. 1816. Histoire naturelle des animaux sans vertèbres. Tomesecond.Paris:Verdière,pp. 568.

MacCord, F.S. \& L.F.L. Duarte. 2002. Dispersion in Populations of Tropiometra carinata (Crinoidea: Comatulida) in the Sao Sebastiao Channel, Sao Paulo State, Brazil. Estuarine, Coastal and Shelf Science 54: 219-225.

Martinez, M.I., E. Alba-Posse, D. Lauretta \& P.E. Penchaszadeh. 2018. Developmental stages in the brooding sea cucumber Cladodactyla crocea (Lesson, 1830) in the Southwestern Atlantic Ocean. Polar Biology 41: 1237-1244.

Martinez M.I., L.P. Arribas, J.J. Berecoechea, M.I. Brogger \& P.E. Penchaszadeh. 2015. Echinoderm diversity in the Southwestern Atlantic. Revista Biología Tropical 63: 115-120.

Martinez S. 2013. Echinoderm Research in Uruguay. In: Alvarado J.J. \& Solís-Marín F.A. (eds.), Echinoderm Research and Diversity in Latin American, pp. 345-354, Springer-Verlag, Berlin.

Messing, C.G. 1997. Living comatulids. In: J.A. Waters, C.G. Maples (eds.), Geobiology of Echinoderms, pp. 3-30, Paleontological Society Papers.

Meyer, D.L., C.G. Messing \& D.B. Macurda. 1978. Zoogeography of tropical western Atlantic Crinoidea (Echinodermata). Bulletin of Marine Science 28: 412-441.

Miquel, S.E. Tablado, A. \& Sodor A. 2007. Curaduría en la Colección nacional de invertebrados de Argentina: aportes a la biodiversidad y biogeografía de gasterópodos terrestres argentinos. Comunicaciones de la Sociedad Malacológica del Uruguay 9 : 113-115.

Mortensen, T.H. 1917. Notocrinus virilis n. g., n. sp. a new viviparous crinoid from the Antarctic Sea. Videnskabelige Meddelelser fra Dansk Naturhistorisk Forening 68: 205-208.

Mortensen, T.H. 1918. The Crinoidea of the Swedish Antarctic Expedition. Wissenschaftliche Ergebnisse der Schwedische Südpolar-Expedition 8: 10-15.

Mortensen, T.H. 1920. Studies in the development of crinoids. Papers from the Department of Marine biology of the Carnegie Institution of Washington 16: $1-94$.

Nigam, N.K. \& C. Raghunathan. 2015. First report of feather star Tropiometra carinata (Lamarck, 1816) to Andaman and Nicobar islands. Records of the Zoological Survey of India 115: 357-360.

O'Loughlin, P.M., G. Paulay, N. Davey, \& F. Michonneau. 2011. The Antarctic region as a marine biodiversity hotspot for echinoderms: Diversity and diversification of sea cucumbers. Deep-Sea Research II 58: 264-275.

Pawson, D.L. 2007. Phylum Echinodermata. Zootaxa 1668: 749-764.

Pennant, T. 1777. Crustacea. Mollusca. Testacea. British Zoology, London 4: 1-154.

Pertossi, R.M., M.I. Brogger, P.E. Penchaszadeh \& M.I. Martinez. 2019. Reproduction and developmental stages in the crinoid Isometra vivipara Mortensen, 1917 from the southwestern Atlantic. Polar Biology 42: 807-816.

Pertossi, R.M., P.E. Penchazadeh \& M.I. Martinez. 2021. Brooding comatulids from the southwestern Atlantic, Argentina (Echinodermata: Crinoidea). Marine Biodiverity 51:59. https://doi.org/10.1007/ s12526-021-01194-9

Pourtalès, L.F. 1868. Contributions to the fauna of the Gulf Stream at great depths. Bulletin Museum of Comparative Zoology 1: 103-142.

Speel, J.A. \& J.H. Dearborn. 1983. Comatulid crinoids from the R/V Eltanin cruises in the Southern Ocean. Antarctic Reserch Series 38: 1-60.

Tablado, A. \& J. Mantinián. 2004. Catálogo de ejemplares tipo de la División Invertebrados del Museo Argentino de Ciencias Naturales. II. Mollusca. Revista del Museo Argentino de Ciencias Naturales, n. s. 6: 363-384.

Tablado, A. \& Venerus L. 2000. Catálogo de ejemplares tipo de la División Invertebrados del Museo Argentino de Ciencias Naturales. I. Porifera, Cnidaria, Mesozoa, Platyhelminthes, Nemertinea, Rotifera, Nematomorpha, Nematoda, Bryozoa, Annelida, Crustacea y Echinodermata. Revista del Museo Argentino de Ciencias Naturales, n. s. 2: 203-236.

Tommasi, L.R. 1969. Lista dos crinóides recentes do Brasil. Contribuições Avulsas do Instituto Oceanográfico da Universidade de São Paulo Série Oceanografia Biológica 9: 1-33.

Tommasi, L.R. \& Aron M. A. 1988d. Equinodermes da plataforma continental do sudoeste do Estado da Bahia. Relatório Interno do Instituto Oceanográfico da Universidade de São Paulo 19: 1-6.

Ventura, C.R.R., M.B.L.S. Campos, L.V. Costa-Lotufo, C.A. Freire, V.F. Hadel, C.L.C. Manso, J.R.M.C. Silva, Y. Tavares \& C.G. Tiago. 2013. Echinoderms from Argentina: Biodiversity, distribution and current state of knowledge. In: Alvarado J.J. \& Solís-Marín F.A. (eds.), Echinoderm Research and Diversity in Latin American, pp. 301-344, Springer-Verlag, Berlin.

WoRMS Editorial Board. 2021. World Register of Marine Species. Available from https://www.marinespecies.org at VLIZ. accessed 02 February 2021. doi:10.14284/170

Doi: 10.22179/REVMACN.23.678

Recibido: 16-III-2021

Aceptado: 3-VI-2021 